\title{
Primary Earners: Lived Experiences of Breadwinner Moms
}

\author{
Rolieza Grace D. Taruc
}

Nueva Ecija University of Science and Technology, Philippines

\begin{abstract}
In the Philippines' culture and tradition, it is customary that men or husbands are the sole providers for the family's needs. As the world progress, women are accepted in the workforce and have been increasingly common in the society that females now can be accepted as the breadwinners of the family. This research focuses on the experiences of women as breadwinners, the great impact on them as breadwinners, as an individual, in the family, and in career advancement. The researcher uses a phenomenological method to bring out the fore experiences and perceptions of individuals from their perspectives. Results showed four essential elements of female breadwinners' experiences: (1) decision making control, (2) feeling pressure and worry, (3) feeling guilt and resentment, and (4) career advancement. With these themes, recommendations focused on giving support to these female teaching staff to cope with their daily struggles in life by tapping the Spiritual Uplift Program and Gender and Development of Nueva Ecija University of Science and Technology (NEUST).
\end{abstract}

Keywords - Career growth, female breadwinners, female individuality, phenomenological approach.

\section{INTRODUCTION}

Traditionally, the designation of men as heads of the households in the Philippines was not only customary but also part of the legal system. It was in the 1950 Civil Code of the Philippines that the husbands designated as the family providers, or the breadwinners of the household, and the wives are into the management of household affairs. It is only in 1988 that the promulgation and implementation of the Family Code of the Philippines where it promotes greater equality in the rights and responsibilities of men and women. It is then giving women the right to work for compensation paving the way for women to work, and to help augment the household expenses. As time evolved, women excel in their job and profession. Statistics on Labor Force Survey Philippines: 2005-2013 showed the preliminary results of the October 2013 Labor Force Survey (LFS) that there is a 0.1 increase in the LFPR for females at $49.8 \%$ (from $49.7 \%$ in 2012), and 0.2 decreases for males at 78.12 (from $78.3 \%$ in 2012). It has been illustrated that the participation of women in the labor force increased than men. Statistics also showed that a total of 2.5 million women were working as government officials, corporate executives, managing proprietors, managers, and supervisors while men in the same group were estimated at 2.4 million. These only show that women now are beginning to hold higher positions for career development and employability than men.
Although female breadwinners are increasingly common in the workplace, little research has focused specifically on the experiences of female breadwinners. Experiences on how they strive to make ends meet with regards to household expenses, the stress and disappointments brought by their workloads in school and at home, not to mention the tensions and disappointments between their husbands and children. The researcher found it essential to gain insights on how these women struggle in their everyday lives and succeed in their endeavors, and at work. With these, this phenomenological research aimed to address some of the preceding issues by what women experience as the breadwinners of the family, its impact on them with regards to their individuality, relationship with their families and career growth found meaning and substance.

\section{METHODOLOGY}

This phenomenological research was conducted to investigate the experiences (Baniaga, Porquerino, Vidad, \& Subia, 2018)of the participants as female breadwinners. The researcher used this approach since it seeks essentially to describe rather than explain, and start from a perspective free from hypotheses or preconceptions (Husserl 1970). This study is conducted to determine if the essential elements identified from the participants' experiences are having a 
great impact on them with regards to their identities, family relationships, and career advancement.

To gather experiences, in-depth interviews were conducted to10 purposively chosen (Subia, 2018) female teaching personnel of NEUST. They have been interviewed and had an in-depth discussion with the researcher. Questions were focused on their perception based on their experiences as the breadwinners in the family. Questions leading to the issues on their individuality, relationship with the husband and children, and issues on career advancement were the focus of the interview.These ten participants had no househelp or nannies and were all living separately from their parents. Their children range from grade 3 to junior high school. Basing on their experiences from their everyday endeavors, their narration and answers were summarized according to common elements and themes to come up with possible recommendations to address the difficulties they are facing in life.

The researcher used three sections in discussing the findings: (1) arranging the data gathered according to themes and topics in order to draw out key issues being discussed by participants, (2) discussion section where the researchermade interpretations and linkages in relation to previous research or commentary, to personal experience or even to commonsense opinions, and developing tentative theories, and (3) final section on issues and implications and formulating plan of activities to helpthe NEUST's female breadwinners.

\section{RESULTS AND DISCUSSION}

Out of the ten participants, six of the disclosed that they are the sole breadwinners in the family where four of them said that their husbands lost their job due to conflict at work, end of the contract, and can no longer stay on the job due to low compensation.Husbands of these six faculty members are trying to find a job but help partially in the household chores,and some do not help at all.The remaining two from the six participants said that their husbandsopted to be "housebands" to take care of the household activities and taking care of children.

Coinciding with the 2007 Bureau of Labor Statistics of America, among all married couples, including those whose husbands aren't necessarily working, $33.5 \%$ of women were making more (money) than their husbands. In this research, the rest of the four female participants who have working husbands, but the ones who have higher salaries are the wives. Two husbands from these four female participants are helping in the household chores while the other two do not help at all.

\section{Issues of Individuality}

When individuality was being discussed, the focus of discussion revolved in being their total characteristics and distinct identity that make them as a particular individual.

When asked about how their individuality is being viewed as the breadwinners of the family, there were disclosures from all of the ten participants, that they have two personalities revolving in their lives. When at home, their role is a mother who attends to the needs of her children,and the other role is at the workplace as an employee and teacher to students.

They cannot get away from their roles as mothers because they feel that although their husbands are attending to their children's' needs: cooking, laundry, and maintaining the house. The participants feel that there is guilt whenever they cannot contribute to household needs because of their workload at school.

As to the area of spending and controlling finances,fivewomen replied that they feel they are more in control of the situation since they are the ones who bring home the butter while the others are earning much higher than their husbands. They are the decision-makers in the family who set the priority on where to spend their earnings. Though sometimes, it leads to arguments with their husbands because the husbands feel that they are still the decisionmakers taking from the traditional view of husbands, while the remaining fiveparticipants talked with their husbands on what to do with the earnings.

All of the participants revealed that as an individual, being the breadwinner of the family makes them strong as a person due to challenges that they have to face in life. Juggling work as a teacher and employee, and work at home is already a big responsibility which makes them proud of themselves. Although they are living a difficult life, they are still gratified that they can endure all of these and accomplish the task as the breadwinners of their families.

They believe in and love their husbands, but for the women whose husbands do not share their ambition, they sometimes struggled to understand this identity difference.

\section{Issues on Relationship with Families}

The ten participants confessed thatalthough being a breadwinner of the family makes them proud of themselves, they are wary of the issue of the masculinity of their husbands.

Participants who are the sole breadwinners of their families discussed the traditional masculine identity of their husbands. Although some of the participants have no qualms about their 
husbands thought of being "housebands",some participants answered that their husbands are concerned with the issue that husbands are no longer the primary breadwinners for their families. Self-respect, the feeling of rejection, and worse, depression and non-motivation to work at home and finding a better job are sometimes the issues of arguments and disagreements between the husbands and wives.

Spending quality time with their children is one of the concerns of all the participants, where they felt they are guilty of because they tend to spend more time at work and even bringing work at home, thus,they spend less quality time with their children. In the study conducted by $\mathrm{C}$. Dacuycuy (2016) on Wages, Housework and Attitudes in the Philippines, she discussed that the male respondent's attitudes have a direct effect on the wife's housework. Wives spendless time on housework when the male participants agree that men should do a larger share of childcare.

Wives also spend more time on housework when the husbandsagree that family life suffers when wives work. These results emphasize the importance of attitudes on gender roles to understand householdoutcomes and are consistent with the dynamics of a household relationship where spouses learn to adaptand adjust to accommodate each other's attitudes, values, and preferences.

Towards the end of the interview, one respondent mentioned that she wishes that her husband will get a job that was in line with her salary and the other respondent said thatshe is hoping that her husband will at least get a job to help augment the expenses of the family.

\section{Issues on Career Advancement}

Statistics conducted by Philippine Commission on Women (2014), states that in October 2010 Labor Force Survey (LFS), a total of 5 million women laborers and unskilled workers and 6.7 million of their male counterparts. Women were engaged as farmers, forestry workers, and fisherfolks valued at 839 thousand compared to 5.1 million men in the same occupation. Likewise, women government officials, corporate executives, managing proprietors, managers, and supervisors were valued at 2.5 million while men in the same groupestimated at 2.4 million.

This survey shows that although men laborers outnumbered women in the field of agriculture, women are more dominant in other fields such as government officials, corporate executives, managing proprietors, managers, and supervisors. This proved that women are beginning to lead in the workforce especially in private companies or government agencies.
The above survey supported this study where it illustrated the impact on the career advancement of working motherswho were working at NEUST, a government institution. They are looking forward to promotion known as the National Budget Circular 461 (NBC 461) for State Universities and Colleges (SUCs) where their status in the university and salary will be upgraded, thus resulting in a higher salary.

However, eight of the participantswhere they revealed that,as Instructors at NEUST, they are having a hard time accomplishing tasks and workload, and at the same time meeting the deadlines because they are struggling to work at household activities and work at the workplace. They are the ones who worry that they will be evaluated poorly in the performance evaluation. Two of the participants who have full-time husbands at home replied that their husbands are supportive of their profession. The husbands do not demand their time to help in the household and taking care of the kids. One of them kidded that herhusband demanded that he should be taken care of at night by the wife. The rest of the participants who have husbands with lower salary said that "kaya namanggawinlahatbasta 'di kami nagaaway", "iniiwasanna lang naminpag-usapankungsino mas mataas angkitabastadapatmabayaranlahatng bayarin", "may usapanna kami kungsino at anoanggagawin para maiwasan ang away"(We can do all things and we talk to settle all issues about salary and to pay all expenses. To avoid conflict we have previous peace agreement).

From these surveys and responses of the participants, the researcher gathered that although there was a decline in the male labor force who belong in higher positions, the husbands no longer live in the notion of being the sole breadwinner of the family. It suggested that in a family, the main breadwinner is the one who has a higher position in the company whereshe/he is working. And in this study, the breadwinners are the wives, who are beginning to have dominant figures in the survey and being supported by the experiences of the participants interviewed by the researcher.

\section{CONCLUSIONS AND RECOMMENDATIONS}

It can be gleaned from the result of the experiences of the female participants and from the surveys conducted by different agencies, there is no doubt that the women have progressed and developed in the labor force. Although husbands are traditionally considered the heads of families in the Philippines, studies indicate that Filipino women actively participate in household decision-making.Also, these findings have implications for women's individuality, their families and career advancement. First on an individual level and issues on a relationship with families, knowing their 
experiences may assist these women in creating and managing their own identities. Thiscan be achieved if open communication is created between the husbands and wives. Knowing that the wives are the breadwinners, it would be helpful for both of them to improve their communication patterns and to maintain harmony in the family by discussing the experiences of these women as the breadwinners and valuing the husbands' contributions in the family. This will also help ease the burden of feeling the pressure and worry of not having quality time with the children where the feeling of guilt and resentment set in.

Women's participation in decision-making is the result of social changes that are affecting family life and the roles of women. Among these changes is the rise in the female labor force, females are given higher positions in the company they are working for. These resulted in a great responsibility on women to provide and support for children's needs and house expenditures. Understanding how these women value careers, and they are driven to work even harder, companies and other agencies should motivate even-for-profit corporations to support these female breadwinners. This research will help the society who has an increasing number of female breadwinners, one that has an impact on women's individuality, issues of family relations and career advancement by formulating plans and activities for them. These will help boost their morale, self-esteem and selfworth, and individuality.

Therefore, to support the female teaching personnel of NEUST in coping with their situation and struggles, the researcher recommends to have plans and activities for them as cited below:

\section{ISSUES/ IMPLICATIONS}

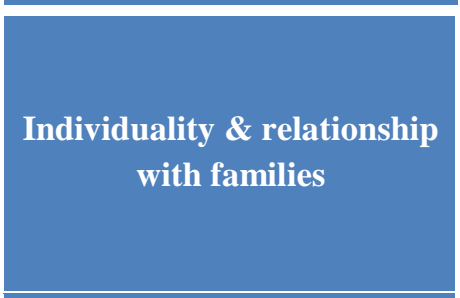

Career Growth

Low morale, self-esteem and valuing self and family

\section{RECOMMENDATION}

Open Communication

Understanding how women value careers and provide motivation for even-for-profit corporations

Series of seminars involving female breadwinners.

Seminars and teachings involving the female teaching staff and their husbands (even husbands are not employees of NEUST)

\section{REFERENCES}

[1] Baniaga, D. N., Porquerino, C. A., Vidad, L. T., \& Subia, G. S. (2018). Steadfastly Dauntless: Excellent Students in the Midst of Challenging Working Environment. International Journal of English Literature and Social Sciences, 3(4), 488492. Retrieved from https://ijels.com/ojs/index.php/ijels/article/view/45

[2] Benitez, Asuncion L (1993), Rethinking the law: Women and Equality

\section{PURPOSE}

Improve communication patterns

-discuss the experiences of women as breadwinners and valuing husbands' contribution

Great responsibility on women to provide support and house expenditures

Boost morale and self-esteem of female teaching staff will result in more motivation, more energized and inspired at work and home.

\section{OBJECTIVE}

To ease the burden of feeling pressure and worry, and feelings of guilt and resentment

To help women motivated to advance in careers and to support female breadwinners

To bring husbands and wives closer and to create avenues for communication for a better understanding of oneself and each other.

[3] Bruce, Juidith and Cynthia B (1993) Finding the ties that bind: Beyond headship and household. New York: The Population Council

[4] Buzzanell, PM \& Turner, EH (2003), Emotions work revealed by jobless discourse, Journal of Applied Communication Research

[5] Dacuycuy, C., (2016) Wages, Housework and Attitudes in the Philippines PIDS

[6] Ehrenreich, B (1983) The Hearts of Men, Garden City: Anchor Ellemers, N (2001) 
[7] Go, Stella (2002), The Filipino family in the eighties, Bangkok: UNESCO Regional Office for Asia and the Pacific

[8] Jannsens, A (1998). The rise and decline of the male breadwinner family: An overview of the debate, In A. Jannsens (Ed.)

[9] Medina, Belen (2001), The Filipino family. Quezon City: University of the Philippines Press

[10] Meisenbach RJ (2010). The Female Breadwinner: Phenomenological Experiences and Gendered Identity in Work/ Family Spaces Mirulao, VA (nd). Female-Headed Households in the Philippines

[11] Philippines Commission on Women Statistics (2014)

[12] Reynolds, T (2001). Black Mothering, paid work and identity, Ethnic and Racial Studies

[13] Sainsbury, D. (1996), Gender, equality and welfare states, Cambridge: Cambridge University Press, (1986)

[14] Santiago, C (2008), Country Gender Profile, JICA

[15] Statistics on Labor Force Participation Rates (LFPR 2013)

[16] Subia, G. (2018) Comprehensible Technique in Solving Consecutive Number Problems in Algebra. Journal of Applied Mathematics and Physics, 6, 447-457. doi: 10.4236/jamp.2018.63041.

[17] 1950 Civil Code of the Philippines

[18] 1988 Family Code of the Philippines 